University of Nebraska - Lincoln

DigitalCommons@University of Nebraska - Lincoln

USDA National Wildlife Research Center - Staff Publications
U.S. Department of Agriculture: Animal and Plant Health Inspection Service

2010

\title{
Temporal Variation in Terrestrial Invertebrate Consumption by Laughing Gulls in New York
}

\author{
Glen E. Bernhardt \\ USDA Wildlife Services, National Wildlife Research Center, 6100 Columbus Avenue, Sandusky, Ohio 44870 \\ Lisa Kutschbach-Brohl \\ USDA Wildlife Services, National Wildlife Research Center, 6100 Columbus Avenue, Sandusky, Ohio 44870 \\ Brian E. Washburn \\ USDA Wildlife Services, National Wildlife Research Center, brian.e.washburn@aphis.usda.gov \\ Richard Chipman \\ USDA Wildlife Services, 1930 Route 9, Castleton, New York 12033 \\ Laura Francoeur \\ Port Authority of New York and New Jersey, John F. Kennedy International Airport, Building 145, Jamaica, \\ New York 11430
}

Follow this and additional works at: https://digitalcommons.unl.edu/icwdm_usdanwrc

Part of the Environmental Sciences Commons

Bernhardt, Glen E.; Kutschbach-Brohl, Lisa; Washburn, Brian E.; Chipman, Richard; and Francoeur, Laura, "Temporal Variation in Terrestrial Invertebrate Consumption by Laughing Gulls in New York" (2010). USDA National Wildlife Research Center - Staff Publications. 861.

https://digitalcommons.unl.edu/icwdm_usdanwrc/861

This Article is brought to you for free and open access by the U.S. Department of Agriculture: Animal and Plant Health Inspection Service at DigitalCommons@University of Nebraska - Lincoln. It has been accepted for inclusion in USDA National Wildlife Research Center - Staff Publications by an authorized administrator of DigitalCommons@University of Nebraska - Lincoln. 


\title{
Temporal Variation in Terrestrial Invertebrate Consumption by Laughing Gulls in New York
}

\author{
GLEN E. BERNHARDT, ${ }^{1}$ LISA KUTSCHBACH-BROHL AND BRIAN E. WASHBURN \\ USDA Wildlife Services, National Wildlife Research Center, 6100 Columbus Avenue, Sandusky, Ohio 44870
}

RICHARD B. CHIPMAN

USDA Wildlife Services, 1930 Route 9, Castleton, New York 12033

AND

\author{
LAURA C. FRANCOEUR \\ Port Authority of New York and New Jersey, John F. Kennedy International Airport, Building 145, Jamaica, \\ New York 11430
}

\begin{abstract}
Laughing gulls (Larus atricilla) are commonly found in many areas of North America and little is known about their diet, particularly in coastal-urban interfaces where gull-aircraft collisions can be a serious concern. The objective of this study was to describe and quantify the consumption of terrestrial invertebrates by laughing gulls at a coastal-urban interface in the northeastern United States. We examined the stomach contents of laughing gulls $(\mathrm{n}=1053)$ collected during wildlife damage management operations at John F. Kennedy International Airport during the summers of 2003 and 2004. Terrestrial invertebrates consumed by laughing gulls represented 2 taxonomic phyla, 4 classes, 15 orders and 40 families. Beetles (Coleoptera) and ants (Hymenoptera) were the most common terrestrial invertebrates consumed by laughing gulls. We found evidence of temporal (i.e., monthly) variation in the frequency of occurrence of terrestrial insects in laughing gull diets. Laughing gull gender and age did not influence the frequency of occurrence of terrestrial insects in gull diets. Terrestrial environments (e.g., areas of turfgrass) appear to provide important foraging locations and food resources for laughing gulls in coastal-urban areas. This information is important for developing effective management approaches to reduce human-gull conflicts, such as gull-aircraft collisions at coastal airports.
\end{abstract}

\section{INTRODUCTION}

The laughing gull (Larus atricilla) is widely distributed in North America, and populations in the northeastern United States have increased during recent decades (Belant and Dolbeer, 1993; Sauer et al., 2008). Laughing gulls nest along the Atlantic coast of the United States (from Maine to Florida), on the Gulf of Mexico coast, and in the Carribbean (Burger and Gochfeld, 1985; Belant and Dolbeer, 1993). In northern latitudes of the United States, laughing gulls nest in colonies located in salt marsh habitats near the coast (Burger and Gochfeld, 1985; Burger, 1996).

Gulls (Larus spp.) are generalists with regard to dietary specialization and use a variety of aquatic and terrestrial habitats, food types and foraging strategies (Buckley and McCarthy, 1994; Burger, 1988; Annett and Pierotti, 1989; Kubetzki and Garthe, 2003). Urban environments in coastal areas (freshwater and marine) provide a potentially diverse source of food for gulls, including items of marine, terrestrial and anthropogenic origin. Although some reported observations of laughing gull feeding habits exist (Bent, 1921; Burger, 1988; Caccamise et al., 1994; Burger and Wagner, 1995), little information is available regarding

\footnotetext{
${ }^{1}$ Corresponding author: e-mail: brian.e.washburn@aphis.usda.gov
} 
laughing gull foraging and prey selection (Burger, 1996), particularly in urban environments.

An abundance of gulls, including laughing gulls, in urban areas results in a variety of conflicts between humans and gulls, including hazards to safe aircraft operations (i.e., bird strikes), problems at landfills, transmission of diseases and parasites through water contamination, damage to buildings and structures, and other nuisance issues (Patton, 1988; Belant, 1997; Dolbeer et al., 2003; Rock, 2005). Integrated wildlife damage management programs that incorporate a variety of tools and techniques are used to manage laughing gull conflicts (Caccamise et al., 1994; Dolbeer et al., 2003; Washburn et al., 2005), but information regarding laughing gull food habits, particularly in or near urban areas, is important for developing new and effective habitat management approaches to reduce gull-human conflicts. For example, reducing terrestrial insect populations that potentially attract foraging laughing gulls could reduce the risk of laughing gull-aircraft collisions at coastal airports.

The objective of this study was to describe and quantify the consumption of terrestrial invertebrates by laughing gulls during summer months at a coastal-urban interface in the northeastern United States. This study was part of a larger research effort examining the foraging ecology and diet of several gull species in the metropolitan New York area.

\section{Methods \\ STUDY AREA}

This study was conducted on lands adjacent to a laughing gull nesting colony in the Joco Marsh island complex in the Gateway National Recreation Area (NRA), Jamaica Bay Unit $\left(40^{\circ} 38^{\prime} \mathrm{N}, 73^{\circ} 47^{\prime} \mathrm{W}\right)$ that borders the John F. Kennedy International Airport (JFKIA) during mid-May to early Sep. 2003 and 2004 (Dolbeer et al., 1997; Fig. 1). Gateway NRA and JFKIA are located on southwestern Long Island, New York. This nesting colony is one of the most northern laughing gull breeding colonies along the East Coast (Washburn et al., 2005). In 2003 and 2004, this laughing gull colony was comprised of an estimated 2199 and 2083 nests, respectively (Washburn et al., 2004). The nesting colony site is composed of several islands in Jamaica Bay, which consist primarily of low salt marsh (typically characterized by Spartina alterniflora) and high salt marsh (dominated by S. patens).

Marine and terrestrial habitats that might provide foraging opportunities for laughing gulls (in the vicinity of the nesting colony) include salt marshes, tidal bays and mudflats, residential lawns and gardens, local parks and other areas of mowed turfgrass, and the airfield and associated areas at JFKIA. The JFKIA airfield is 1995 ha in size and is characterized by large areas of cool-season turfgrasses, sparse weedy vegetation, and some small trees and shrubs (Barras et al., 2000). Gulls also have access to anthropogenic food sources (e.g., human refuse) in the surrounding urban and suburban areas.

Dietary analyses. - Laughing gulls $(\mathrm{n}=1053)$ were collected at JFKIA as a stratified random sample (i.e., every fifth gull shot was collected) from laughing gulls shot by professional biologists using 12-gauge shotguns from 19 May 2003 to 5 Sep. 2003 and from 18 May 2004 to 1 Oct. 2004 as part of an integrated wildlife damage management program to reduce gullaircraft collisions (Dolbeer et al., 1993; Washburn et al., 2005). The digestive system of each bird was injected with $70 \%$ ethyl alcohol at the time of collection (Rosenberg and Cooper, 1990). Each gull specimen was labeled, placed in a plastic bag and frozen within $6 \mathrm{~h}$ of collection. Frozen gulls were shipped to Sandusky, Ohio for necropsy.

We thawed each gull prior to laboratory necropsy. Laughing gulls were assigned to age classes [Age $0=$ hatching-year; Age $1=1$ y old (subadult); Age $2=2$ y old (adult); and Age 

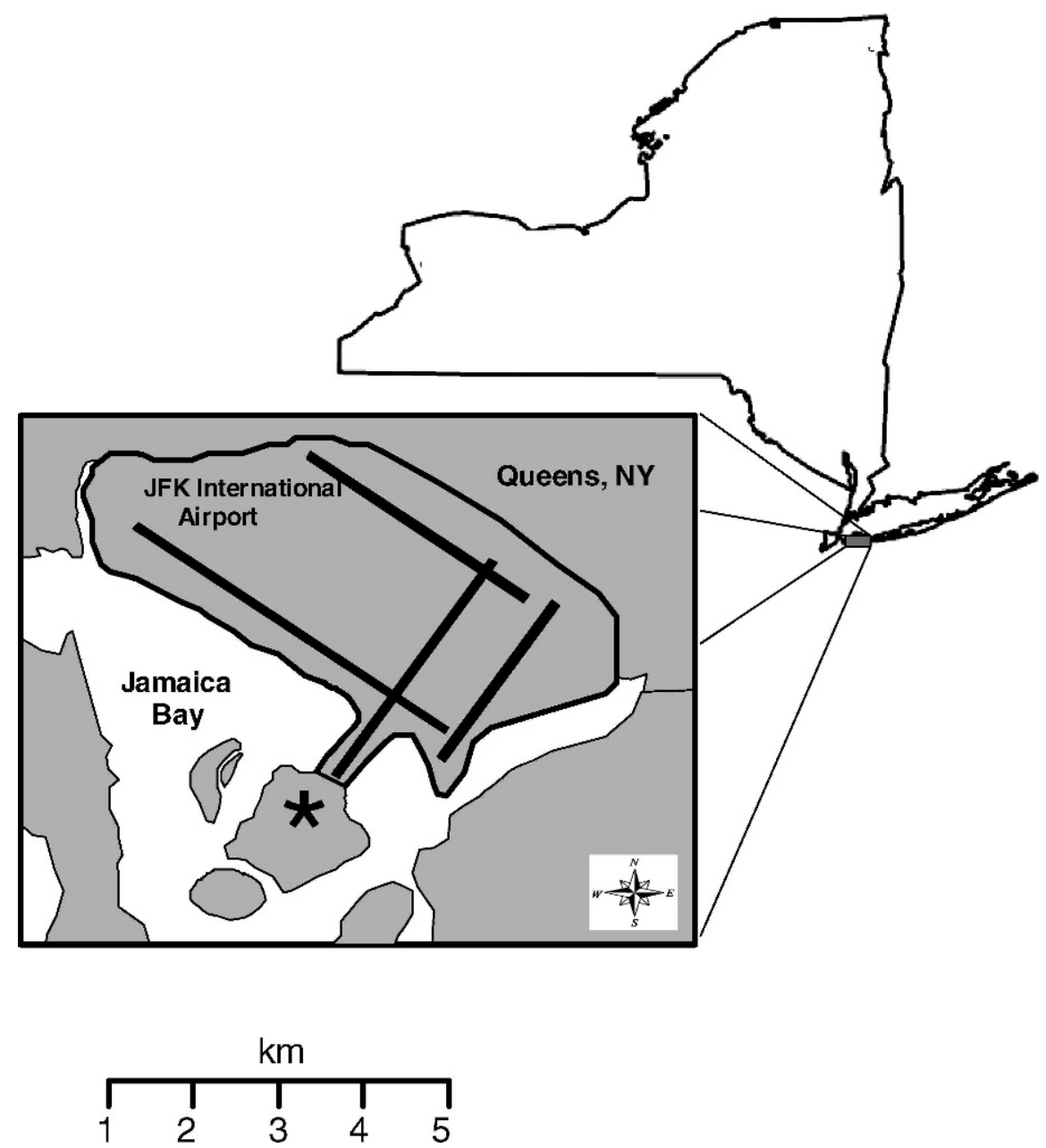

Fig. 1.-Location of the laughing gull nesting colony, represented by an asterisk (*), relative to Gateway National Recreation Area and the John F. Kennedy International Airport

$3+=\geq 3$ y old (adult)] based on plumage (Belant and Dolbeer, 1996) and to gender classes based on internal anatomy. The contents of the stomach, proventriculus, and esophagus [hereafter this entire complex is referred to as the stomach (McLelland, 1991)] of each laughing gull were removed and examined. All terrestrial invertebrate prey and fragmented remains were removed and stored in $70 \%$ ethanol for further analyses.

Unaided eyes, $5 \times$ hand lenses, and $20 \times$ binocular microscopes were used to identify the invertebrates or fragments of invertebrate prey to the lowest possible taxonomic level. Although some invertebrate specimens had extreme damage (presumably from the digestive process) which precluded identification beyond the taxonomic level of order, we identified many specimens to the subfamily or genus level. We followed the classification and nomenclature described in Triplehorn and Johnson (2005) for arthropods and in Edwards and Lofty (1972) for annelids. Other pertinent references (e.g., Dillon and Dillon, 
1961; Borror and White, 1970; Helfner, 1987) were used for family and genus designations. Due to high levels of damage to invertebrate prey specimens from the ingestive and digestive processes and the paucity of some samples, we made no effort to quantify the exact number or mass of terrestrial invertebrates found within a particular laughing gull stomach as these numbers would be subject to large errors (Duffy and Jackson, 1986; Rosenberg and Cooper, 1990; Granadeiro et al., 2002).

Data analyses.-We calculated frequency of occurrence $(\%)$ as the number of gulls that had consumed a given terrestrial insect taxon (e.g., family), expressed as a percentage of the total number of all laughing gulls $(n=1053)$ collected and examined (Duffy and Jackson, 1986; Catry et al., 2006). We calculated the percent taxon occurrences of a given terrestrial insect taxon (e.g., order) as the number of individual occurrences of that taxon, expressed as a percentage of the total number of all taxon occurrences (Duffy and Jackson, 1986; Granadeiro et al., 2002). We found no significant differences between years (chi-squared tests; all $\mathrm{P}>0.05$ ), thus we combined data between years to assess the effects of season (i.e., month of collection) and laughing gull gender and age on terrestrial invertebrate consumption. In addition, we removed laughing gulls of unknown gender $(n=5)$ or age $(n$ $=39$ ) from the appropriate datasets prior to analyses. We compared the frequency of occurrence $(\%)$ of terrestrial invertebrate prey by month of collection, gender and age class for laughing gulls using chi-square tests and considered differences significant at $\mathrm{P} \leq 0.05$ (Zar, 1996).

\section{RESULTS}

Laughing gulls consumed a variety of prey items, including foods of terrestrial, marine and anthropogenic origin. Terrestrial invertebrates were present and identified in 22\% (229 of 1053) of the laughing gulls necropsied during this study. Only 2\% (19 of 1053) of the laughing gull examined had completely empty stomachs.

Laughing gulls consumed a variety of terrestrial invertebrates, representing a total of two phyla, four taxonomic classes, 15 orders and 40 families. One gull consumed terrestrial invertebrates from five individual orders and seven identified families, including: Hymenoptera: Formicidae (ants), Diptera: Rhagionidae (snipe flies), Coleoptera: Scarabaeidae (scarab beetles), Coleoptera: Elateridae (click beetles), Coleoptera: Carabidae (ground beetles), Lepidoptera: Noctuidae (noctuid moths) and Isopoda: Armadillidiidae (pill bugs).

A total of 348 terrestrial invertebrate taxon occurrences was found among all laughing gull samples (i.e., individual laughing gulls consumed one or more terrestrial invertebrate prey). The most commonly consumed terrestrial invertebrate prey items (93.4\%) were insects (class Hexapoda), although laughing gulls also consumed non-insect terrestrial invertebrate taxa. Spiders (Arachnida: Araneae), pill bugs (Isopoda: Armadillidiidae), and earthworms (Oligochaeta: Lumbricidae) were present in six, one and 16 laughing gulls examined, respectively. Given the dominance of insects within the terrestrial invertebrate component of the diet of laughing gulls, we removed the non-insect terrestrial invertebrates from datasets prior to conducting further analyses.

The terrestrial insect prey consumed most frequently was beetles (Coleoptera), which accounted for $46.8 \%$ of the total insect taxon occurrences (Table 1). Individual laughing gulls often consumed individuals from more than one beetle family. Among the seven beetle families identified as laughing gull food items, the Scarabaeidae (scarab beetles) occurred most frequently and comprised $24.9 \%$ of all insect taxon occurrences (Table 1). 
TABLE 1.-Number of taxon occurrences of terrestrial insects consumed by laughing gulls collected at the John F. Kennedy International Airport during 2003 and 2004. Note: Individual gulls might have consumed more than one insect order and/or insect family within an insect order

\begin{tabular}{|c|c|c|c|}
\hline Order & Family & Common name & No. of taxon occurrences \\
\hline Blattodea & Blattidae & Cockroach & 13 \\
\hline Blattodea total & & & 13 \\
\hline \multirow[t]{8}{*}{ Coleoptera } & Scarabaeidae & Scarab beetle & 81 \\
\hline & Carabidae & Ground beetle & 29 \\
\hline & Curculionidae & Weevil & 9 \\
\hline & Elateridae & Click beetle & 7 \\
\hline & Lucanidae & Stag beetle & 3 \\
\hline & Histeridae & Hister beetle & 2 \\
\hline & Chrysomelidae & Leaf beetle & 1 \\
\hline & Unidentified & Beetle & 20 \\
\hline Coleoptera total & & & 152 \\
\hline \multirow[t]{12}{*}{ Diptera } & Tipulidae & Crane fly & 8 \\
\hline & Tabanidae & Biting fly & 4 \\
\hline & Calliphoridae & Blow fly & 2 \\
\hline & Tachinidae & Tachinid fly & 2 \\
\hline & Chironomidae & Midge & 1 \\
\hline & Culicidae & Mosquito & 1 \\
\hline & Dolichopodidae & Long-legged fly & 1 \\
\hline & Muscidae & Muscid fly & 1 \\
\hline & Psycodidae & Moth fly & 1 \\
\hline & Rhagionidae & Snipe fly & 1 \\
\hline & Syrphidae & Syrphid fly & 1 \\
\hline & Unidentified & Fly & 11 \\
\hline Diptera total & & & 34 \\
\hline \multirow{6}{*}{ Heteroptera-Hemiptera } & Pentatomidae & Stink bug & 9 \\
\hline & Corixidae & Water boatman & 3 \\
\hline & Cydnidae & Burrowing bug & 2 \\
\hline & Notonectidae & Backswimmer & 1 \\
\hline & Scutelleridae & Shield-backed bug & 1 \\
\hline & Unidentified & Bug & 1 \\
\hline Hemiptera total & & & 18 \\
\hline \multirow[t]{2}{*}{ Heteroptera-Homoptera } & Cicadidae & Cicada & 3 \\
\hline & Cicadellidae & Leafhopper & 1 \\
\hline Homoptera total & & & 4 \\
\hline \multirow[t]{4}{*}{ Hymenoptera } & Formicidae & Ant & 63 \\
\hline & Ichneumonidae & Ichneumonid wasp & 5 \\
\hline & Brachonidae & Brachonid wasp & 2 \\
\hline & Unidentified & Wasp or bee & 2 \\
\hline Hymenoptera total & & & 72 \\
\hline \multirow[t]{3}{*}{ Lepidoptera } & Noctuidae & Noctuid moth & 12 \\
\hline & Pterophoridae & Plume moth & 1 \\
\hline & Unidentified & Moth or butterfly & 2 \\
\hline Lepidoptera total & & & 15 \\
\hline Mallophaga & Laemchothridae & Chewing louse & 1 \\
\hline Mallophaga total & & & 1 \\
\hline
\end{tabular}


TABLE 1.-Continued

\begin{tabular}{lllc}
\hline \hline \multicolumn{1}{c}{ Order } & \multicolumn{1}{c}{ Family } & Common name & No. of taxon occurrences \\
\hline Odonata & Libellulidae & Dragon fly & 1 \\
Odonata total & & & $\mathbf{1}$ \\
Orthoptera & Acrididae & Grasshopper & 7 \\
& Tettigoniidae & Katydid & 2 \\
& Gryllacridae & Camel cricket & 1 \\
Orthoptera total & Unidentified & Orthopteran & 1 \\
Unidentified insects & & & $\mathbf{1 1}$ \\
Total Insect Occurrences & & & $\mathbf{4}$ \\
\hline
\end{tabular}

Japanese beetles (Popillia japonica) and May beetles (Phylophaga spp.), in their adult form, were consumed by laughing gulls more frequently than other insect prey items (Table 2).

Wasps and ants (Hymenoptera) were also frequently preyed upon by laughing gulls and accounted for $22.2 \%$ of the total insect taxon occurrences (Table 1). Ants (Formicidae) were a common laughing gull food item, comprising $87.5 \%$ of Hymenopteran taxon occurrences and $19.4 \%$ of all insect taxon occurrences (Table 1). Laughing gulls consumed individuals from both ant subfamilies (Table 2).

Flies (Diptera), true bugs (Heteroptera-Hemiptera), moths (Lepidoptera), cockroaches (Blattodea), grasshoppers (Orthoptera) and other insects were also terrestrial prey items consumed by laughing gulls (Table 1). Although flies represented only $10.5 \%$ of all insect taxon occurrences, we identified individuals from eleven fly families in gull stomachs (Table 1).

Frequency of occurrence of all terrestrial insects $\left(\chi^{2}=31.81\right.$, df $\left.=3, \mathrm{P}<0.0001\right)$, Coleoptera $\left(\chi^{2}=32.51, \mathrm{df}=3, \mathrm{P}<0.0001\right)$ and Hymenoptera $\left(\chi^{2}=16.57, \mathrm{df}=3, \mathrm{P}=\right.$ $0.001)$ in laughing gull diets varied among the summer months. The proportion of laughing gulls that consumed terrestrial insects in Jul. was higher than in Aug. (Fig. 2).

The frequency of occurrence of terrestrial insects in the diet of male laughing gulls $(20.5 \% ; \mathrm{n}=570)$ was not different $\left(\chi^{2}=3.74\right.$, $\left.\mathrm{df}=1, \mathrm{P}=0.06\right)$ than the frequency of occurrence of terrestrial insects in the diet of females $(20.3 \% ; \mathrm{n}=478)$. Similarly, the proportion of male and female laughing gulls that consumed beetles (males $=12.3 \%$, females $=12.1 \%$ ) and wasps and ants (males $=5.8 \%$, females $=6.5 \%$ ) was not different (beetles: $\chi^{2}=2.25$, df $=1, \mathrm{P}=0.13$; wasps and ants: $\chi^{2}=0.13$, $\mathrm{df}=1, \mathrm{P}=0.72$ ).

The proportion of laughing gulls that consumed terrestrial insects was not related to gull age (Fig. 3A). Frequency of occurrence $(\%)$ of all terrestrial insects $\left(\chi^{2}=1.53\right.$, df $=2, \mathrm{P}=$ $0.47)$, Coleoptera $\left(\chi^{2}=2.65, \mathrm{df}=2, \mathrm{P}=0.27\right)$, and Hymenoptera $\left(\chi^{2}=2.54, \mathrm{df}=2, \mathrm{P}=\right.$ 0.28 ) in laughing gull diets did not vary among gull age classes. Similarly, all terrestrial insects $\left(\chi^{2}=0.23\right.$, df $\left.=3, \mathrm{P}=0.97\right)$, Coleoptera $\left(\chi^{2}=1.58, \mathrm{df}=3, \mathrm{P}=0.67\right)$, and Hymenoptera $\left(\chi^{2}=2.79, \mathrm{df}=3, \mathrm{P}=0.43\right)$ were consumed by hatching-year, sub-adult and adult laughing gulls in equal frequency during Aug. (Fig. 3B).

\section{Discussion}

Our data suggest laughing gulls foraged upon a diverse assemblage of terrestrial invertebrates. Beetles (Coleoptera) and ants (Hymenoptera) comprised approximately twothirds of the terrestrial insect food items consumed by laughing gulls in this study. We 
TABLE 2.-Total number of laughing gulls collected at John F. Kennedy International Airport, New York during 2003 and 2004 that had consumed terrestrial insects that could be identified to specific genera or subfamilies and the frequency of occurrence $(\%)$ of those insect taxon in laughing gulls that consumed terrestrial insects. Subfamilies are denoted by parenthesis

\begin{tabular}{|c|c|c|c|c|c|}
\hline Order & Family & $\begin{array}{l}\text { Genus or } \\
\text { subfamily }\end{array}$ & Common name & No. of gulls & $\begin{array}{c}\text { Frequency of } \\
\text { occurrence }(\%)\end{array}$ \\
\hline Blattodea & Blattidae & Periplaneta & $\begin{array}{l}\text { American } \\
\text { cockroach }\end{array}$ & 8 & 3.5 \\
\hline \multirow[t]{7}{*}{ Coleoptera } & Scarabaeidae & Popillia & Japanese beetle & 28 & 12.3 \\
\hline & Scarabaeidae & Phylophaga & May beetle & 20 & 8.7 \\
\hline & Scarabaeidae & Serica & Jun. beetle & 7 & 3.1 \\
\hline & Scarabaeidae & Euphoria & Chafer & 3 & 1.3 \\
\hline & Carabidae & Calasoma & Caterpillar hunter & 9 & 3.9 \\
\hline & Elateridae & Conoderus & Click beetle & 1 & 0.4 \\
\hline & Elateridae & Melanotus & Click beetle & 1 & 0.4 \\
\hline Diptera & Tabanidae & Tabanus & Deer fly & 2 & 0.9 \\
\hline $\begin{array}{l}\text { Heteroptera/ } \\
\text { Homoptera }\end{array}$ & Cicadidae & Tibicen & Annual cicada & 3 & 1.3 \\
\hline \multirow[t]{3}{*}{ Hymenoptera } & Formicidae & (Formicinae) & Formicid ant & 15 & 6.6 \\
\hline & Formicidae & Camponotus & Carpenter ant & 5 & 2.2 \\
\hline & Formicidae & (Myrmicinae) & Myrmicid ant & 35 & 15.3 \\
\hline \multirow[t]{4}{*}{ Orthoptera } & Acrididae & Melanoplus & $\begin{array}{l}\text { Spur-throated } \\
\text { grasshopper }\end{array}$ & 5 & 2.2 \\
\hline & Acrididae & Dissosteira & $\begin{array}{l}\text { Band-winged } \\
\text { grasshopper }\end{array}$ & 1 & 0.4 \\
\hline & Tettigoniidae & Conocephalus & Meadow katydid & 1 & 0.4 \\
\hline & Tettigoniidae & Neoconocephalus & $\begin{array}{c}\text { Cone-headed } \\
\text { katydid }\end{array}$ & 1 & 0.4 \\
\hline
\end{tabular}

suspect laughing gulls opportunistically preyed upon these insects when they encountered them while foraging in terrestrial habitats.

Although laughing gulls might have captured some insects by aerial hawking (e.g., flies), many invertebrates preyed upon by laughing gulls are non-volant. The presence of these invertebrates (e.g., spiders, earthworms) in the gull stomachs indicates the gulls were likely foraging by picking up food items from the ground (Burger, 1988) or by gleaning insects from vegetation. Further, consumption of insects that occur in specific terrestrial habitats suggest that laughing gulls were foraging in those terrestrial habitats. For example, Japanese beetles and other beetles are associated with areas of managed cool-season turfgrass (Potter and Held, 2002; Hamilton et al., 2007), suggesting that laughing gulls likely were foraging in parks, residential lawns or potentially on the JFKIA airfield. Cockroaches (Blattodea: Blattidae) are usually associated with human dwellings and refuse (Triplehorn and Johnson, 2005); thus, we suspect laughing gulls likely consumed these insects while foraging near human enterprises, such as refuse handling bins or buildings.

Our findings are in agreement with other reported information and studies describing the food habits of laughing gulls. Laughing gulls have been observed foraging on earthworms, particularly following rain events (Bent, 1921; Burger and Wagner, 1995). Caccamise et al. (1994) found that beetles (predominantly Japanese beetles), ants and other 


\section{(A)}

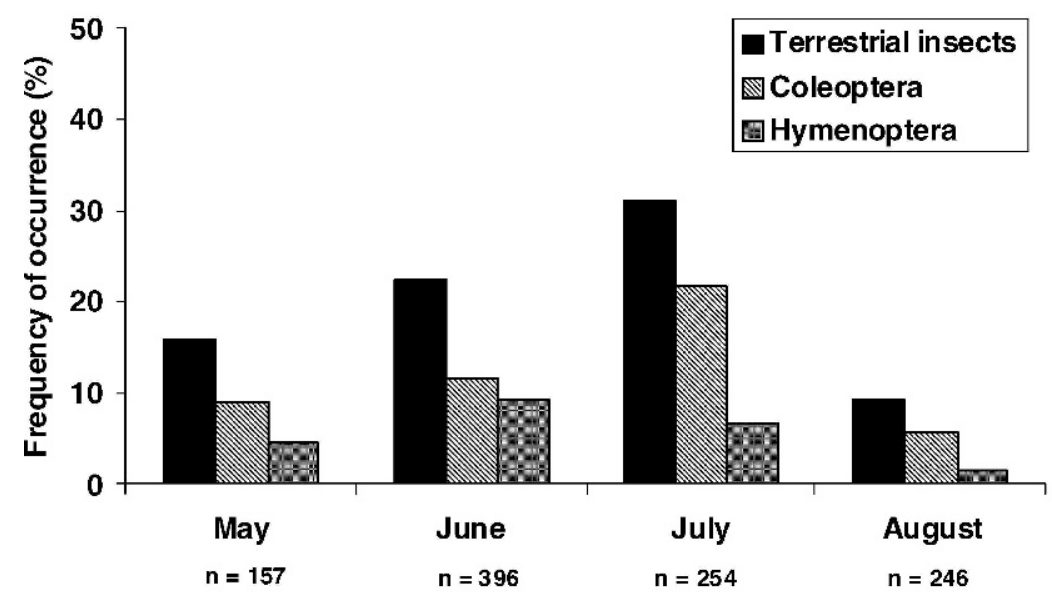

(B)

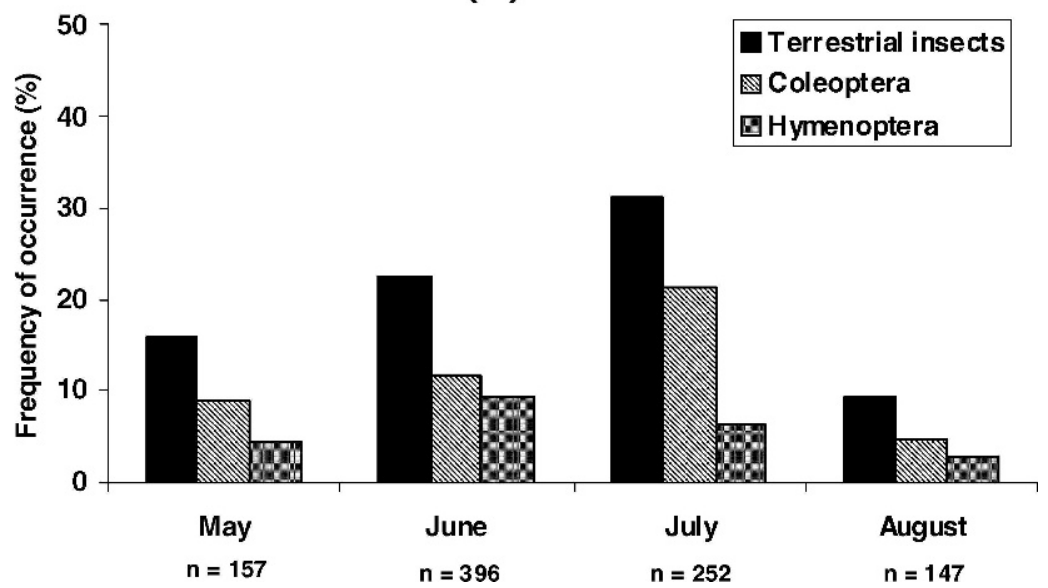

Fig. 2.-Frequency of occurrence (\%) of terrestrial insects, Coleoptera (beetles) and Hymenoptera (wasps and ants) in the diet of laughing gulls by month of gull collection for (A) hatching-year (HY), Age 1, Age 2 and Age 3 laughing gulls (pooled across years and age classes) and (B) Age 1, Age 2 and Age 3 laughing gulls only (pooled across years and age classes)

terrestrial insects were the most important food items to laughing gulls foraging at the Atlantic City International Airport in Atlantic City, New Jersey. Similarly, scarab beetles (Scarabidae) and ground beetles (Carabidae) were consumed by laughing gulls presumably foraging in grassland areas at JFKIA (Buckley and McCarthy, 1994). 
(A)

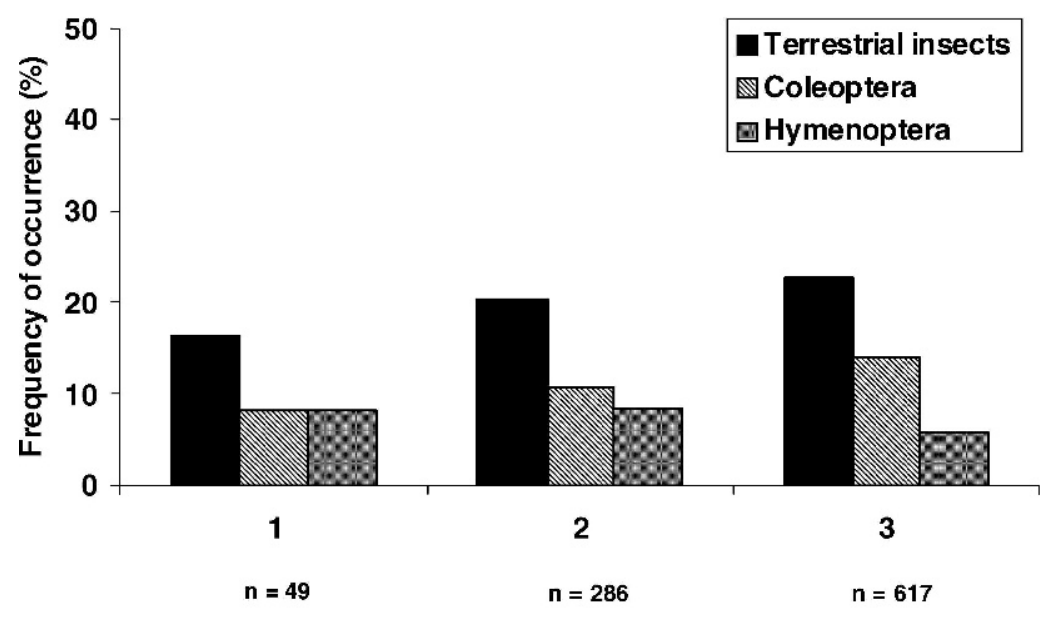

(B)

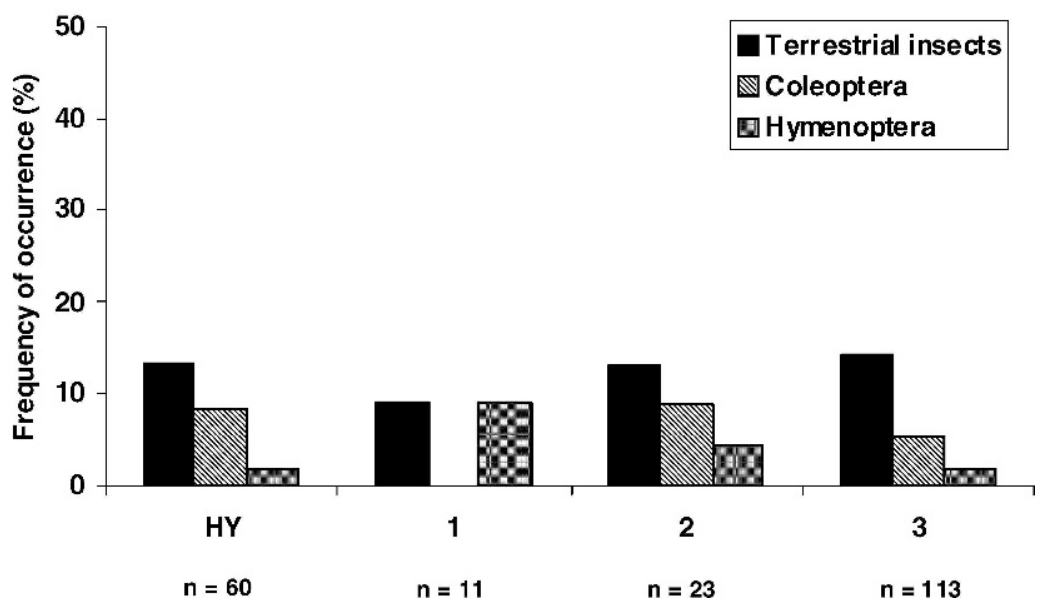

Fig. 3.-Frequency of occurrence (\%) of terrestrial insects, Coleoptera (beetles) and Hymenoptera (wasps and ants) in the diet of laughing gulls of varying age classes for (A) Age 1, Age 2 and Age 3 laughing gulls (pooled between years and months) and (B) HY, Age 1, Age 2 and Age 3 laughings gull in Aug. only (pooled between years). HY represents (Age 0) hatching-year laughing gulls, Age 1 represents 1-yr-old (subadult) laughing gulls, and Age 2 and Age $3+$ represent adult laughing gulls 
Temporal (i.e., monthly) variation in the frequency of terrestrial insect consumption by laughing gulls was likely related to seasonal changes in terrestrial invertebrate communities and abundance of selected prey items. For example, adult Japanese beetles emerge in late Jun. and Jul. (Potter and Held, 2002; Hamilton et al., 2007), which corresponds to the highest proportion of beetle (Coleoptera) consumption by laughing gulls. The abundance of some terrestrial insects might be lower during Aug. (compared to earlier months) and therefore less available to foraging gulls.

Although the diet information from our study is indicative of self-feeding by laughing gulls (Ydenberg, 1994), breeding adults are also provisioning nestlings during late Jun. and Jul. (Burger, 1986; Washburn et al., 2004). Laughing gulls travel considerable distances and utilize inland areas (away from breeding colonies located in salt marshes) when provisioning nestlings (Dolbeer et al., 1993; Dosch, 2003). Consequently, laughing gull nestling diets contain a large amount of foods of terrestrial (e.g., insects) and anthropogenic origin (Buckley and McCarthy, 1994; Dosch, 1997; Knoff et al., 2002). Terrestrial invertebrates, in particular those abundant and presumably available to foraging gulls during the nestling period, likely provide an important food resource that is exploited for both self-feeding adult laughing gulls and nutritionally important provisions for growing laughing gulls chicks (Ydenberg, 1994; Caccamise et al., 1994; Dosch, 1997; Davoren and Burger, 1999).

Gender- and age-related differences in feeding behavior and foraging efficiency have been found in many gulls and terns, including laughing gulls (Burger and Gochfeld, 1983; Burger, 1988). In this study, we did not find differences in the frequency of occurrence of consumption of terrestrial invertebrates among laughing gull gender or age groups. Terrestrial invertebrates were a food resource utilized equally among hatching-year, subadult and adult laughing gulls of both genders. Interestingly, our findings suggest hatchingyear laughing gulls have the necessary foraging skills to effectively exploit terrestrial invertebrates as a food resource.

The terrestrial invertebrates we observed in the digestive tracts of collected gulls might be somewhat biased in reflecting the terrestrial invertebrates consumed by foraging laughing gulls. Differential digestibility of consumed prey items (e.g., marine and terrestrial invertebrates, plant material) and associated potential biases in dietary studies has been documented in a variety of birds, including waterfowl (Briggs et al., 1985; Bourget et al., 2007; Anderson et al., 2008), corvids (Berrow et al., 1992), blackbirds (Williams and Jackson, 1981) and passerines (Dillery, 1965; Custer and Pitelka, 1975). We suspect this is also true of invertebrates eaten by gulls. Invertebrates with less rigid exoskeletons might have been digested quickly or sustained more physical damage while being eaten (thus not allowing identification). In contrast, the cuticle of elytra (forewings) of beetles are among the strongest within insect groups and their persistence in gull stomachs could have increased our ability to detect and identify consumed beetles relative to other insects and non-insect terrestrial invertebrates (e.g., earthworms) (Vincent and Wegst, 2004).

Custer and Pitelka (1975) found that no trace remained of spiders approximately 18 min after consumption and no trace of both larval and adult crane flies (Tipulidae) and muscid flies (Muscidae) after $35 \mathrm{~min}$ in snow buntings. Laughing gulls in this study contained spiders and flies from both of these Dipteran families in recognizable form, suggesting the gulls likely consumed these insects in a terrestrial habitat a relatively short time (e.g., $45 \mathrm{~min}$ ) prior to collection.

Our finding that terrestrial invertebrates are an important food source for laughing gulls, combined with information from other studies, might be useful for the development and 
enhancement of wildlife damage management methods to alleviate human-laughing gull conflicts (Caccamise et al., 1994; Belant, 1997). For example, if specific terrestrial habitats used by foraging laughing gulls (e.g., airfields, parks) could be identified and managed to reduce their attractiveness (through habitat management practices such as pesticide applications), the risk of gull-aircraft collisions could be lowered by (1) altering flight paths used by gulls moving between colony locations and foraging sites or (2) reducing the time gulls spend foraging on airfield grassland habitats.

In summary, laughing gulls are generalists with regard to their use of aquatic and terrestrial habitats and foraging strategies. The findings from this food habits study suggest that invertebrates from terrestrial habitats are an important and diverse source of food for laughing gulls during summer months. Scarab beetles (Scarabaeidae) and ants (Formicidae) comprised much of the terrestrial invertebrates consumed by laughing gulls. Earthworms, flies and other invertebrates were also preyed upon by foraging gulls. We found evidence of temporal (i.e., monthly) variation in the frequency of occurrence of terrestrial insects in laughing gull diets. Food habit analyses indicate that laughing gulls spent some time actively foraging in terrestrial habitats (e.g., parks, residential lawns, airfields) within urban and suburban areas. This information is important for developing effective management approaches to reduce human-gull conflicts.

Acknowledgments. - Funding and support for this project was provided by the Port Authority of New York and New Jersey and USDA-APHIS Wildlife Services. We thank the John F. Kennedy International Airport Operations staff, especially S. Nowak, for logistical assistance and the professional wildlife biologists from USDA-APHIS Wildlife Services, especially D. Slater, for securing bird specimens for this study. D. Helon, J. Dierker and S. Brent provided assistance during necropsy. We thank B. Blackwell, T. DeVault, T. Seamans, and 2 anonymous reviewers for comments on an earlier version of this manuscript. The National Wildlife Research Center Institutional Animal Care and Use Committee approved procedures involving laughing gulls in this study (QA-1057).

\section{Literature Cited}

Anderson, E. M., J. R. Lovvorn and M. T. Wilson. 2008. Reevaluating marine diets of surf and whitewinged scoters: interspecific differences and the importance of soft-bodied prey. Condor, 11:285-295.

Annett, C. and R. Pierotti. 1989. Chick hatching as a trigger for dietary switching in the Western gull. Colon. Waterbirds, 12:4-11.

Barras, S. C., R. A. Dolbeer, R. B. Chipman, G. E. Bernhardt and M. S. Carrara. 2000. Bird and small mammal use of mowed and unmowed vegetation at John F. Kennedy International Airport, 1998 to 1999. Proc. Verteb. Pest Conf., 19:31-36.

Berrow, S. D., T. C. Kelly and A. A. Myers. 1992. The diet of coastal breeding hooded crows Corvus corone cornix. Ecography, 15:337-346.

BeLANT, J. L. 1997. Gulls in urban environments: landscape-level management to reduce conflict. Landsc. Urb. Plan., 38:245-258.

AND R. A. Dolbeer. 1993. Population status of nesting laughing gulls in the United States 19771991. Am. Birds, 47:220-224.

AND — 1996. Age classification of laughing gulls based on summer plumage. J. Field Ornith., 67:565-574.

BENT, A. C. 1921. Life histories of North American gulls and terns. U.S. National Museum Bulletin. 113.

Borror, D. J. AND R. E. White. 1970. A field guide to the insects of America north of Mexico. Houghton Mifflin Company, Boston, Massachusetts. 494 p.

Bourget, D., J. L. Savard And M. Guillemette. 2007. Distribution, diet, and dive behavior of Barrow's and common goldeneyes during spring and autumn in the St. Lawrence estuary. Waterbirds, 30:230-240. 
Briggs, S. V., M. T. Maher And R. P. Palmer. 1985. Bias in food habits of Australian waterfowl. Austral. Wildl. Res., 12:507-514.

Buckley, P. A. And M. G. McCarthy. 1994. Insects, vegetation, and the control of Laughing Gulls (Larus atricilla) at John F. Kennedy International Airport, New York City. J. Appl. Ecol., 31:291-302.

Burger, J. 1988. Foraging behavior in gulls: differences in method, prey, and habitat. Colon. Waterbirds, 11:9-23.

1996. Laughing gull (Larus atricilla). The Birds of North America, No. 225. A. Poole and F. Gill (eds.). The Birds of North America, Inc., Philadelphia, Pennsylvania. 28 p.

- AND M. GoChFELD. 1983. Feeding behavior in laughing gulls: compensatory site selection by young. Condor, 85:467-473.

- AND - 1985. Nest site selection by laughing gulls: comparison of tropical colonies (Culebra, Puerto Rico) with temperate colonies (New Jersey). Condor, 87:364-373.

— AND L. WAGner. 1995. Laughing gull, p. 375-380. In: L. E. Love and R. M. Lyman (eds.). Living resources of the Delaware Estuary. DELEP Report Number 95-07, Partnership for the Delaware Estuary, Wilmington, Delaware.

Caccamise, D. F., J. J. Dosch, K. Bennett, L. M. Reed and L. Delay. 1994. Management of bird strike hazards at airports: a habitat approach. Bird Strike Comm. Eur., 22:285-306.

Catry, T., J. A. Ramos, J. Martins, F. Peste, S. Trigo, V. H. Paiva, A. Almeida, A. Luis, J. Palma and P. J. ANDRADE. 2006. Intercolony and annual differences in the diet and feeding ecology of little tern adults and chicks in Portugal. Condor, 108:366-376.

Custer, T. W. And F. A. Pitelka. 1975. Correction factors for prey taken by Snow Buntings (Plectrophenix nivalis). Condor, 77:210-212.

Davoren, G. K. And A. E. Burger. 1999. Differences in prey selection and behavior during self-feeding and chick provisioning in rhinoceros auklets. Anim. Behav., 58:853-863.

Dillery, D. G. 1965. Post-mortem digestion of stomach contents in the Savannah Sparrow. Auk, 82:281.

Dillon, E. S. AND L. S. Dillon. 1961. A manual of common beetles of Eastern North America. Row, Peterson, and Company, Evanston, Illinois. 884 p.

Dolbeer, R. A., J. L. Belant and G. E. Bernhardt. 1997. Aerial photography techniques to estimate populations of laughing gulls in Jamaica Bay, New York, 1992-1995. Colon. Waterbirds, 20:8-13. , - AND J. L. Sillings. 1993. Shooting gulls reduces strikes with aircraft at John F. Kennedy International Airport. Wildl. Soc. Bull., 21:442-450.

Dosch, J. J. 1997. Diet of nestling laughing gulls in southern New Jersey. Colon. Waterbirds, 20:273-281. 2003. Movement patterns of adult laughing gulls Larus atricilla during the nesting season. Acta Ornith., 38:15-25.

Duffy, D. C. ANd S. JACKSON. 1986. Diet studies of seabirds: a review of methods. Colon. Waterbirds, 9:1-17.

Edwards, C. A. ANd J. R. Lofty. 1972. Biology of earthworms. Chapman and Hall Ltd., London, United Kingdom. 283 p.

Granadeiro, J. P., L. R. Monteiro, M. C. Silva and R. W. Furness. 2002. Diet of common terns in the Azores, Northeast Atlantic. Waterbirds, 25:149-155.

Hamilton, R. M., R. E. Foster, T. J. Gibb, C. S. Sadof, J. D. Holland and B. A. Engel. 2007. Distribution and dynamics of Japanese beetles along the Indianapolis airport perimeter and the influence of land use on trap catch. Environ. Entom., 36:287-296.

Helfner, J. R. 1987. How to know the grasshoppers, crickets, cockroaches and their allies. William C. Brown Publishing, Dubuque, Iowa. 363 p.

Knoff, A. J., S. A. MacKo, R. M. Erwin and K. M. Brown. 2002. Stable isotope analysis of temporal variation in the diets of pre-fledged laughing gulls. Waterbirds, 25:142-148.

Kubetzki, U. and S. Garthe. 2003. Distribution, diet, and habitat selection by four sympatrical gull species in the southeastern North Sea. Marine Biol., 143:199-207.

McLelland, J. 1991. The digestive system, p. 27-30. In: M. Brooke and T. Birkhead (eds.). The Cambridge Encyclopedia of Ornithology. Cambridge University Press, Cambridge, United Kingdom.

PatTon, S. R. 1988. Abundance of gulls at Tampa Bay landfills. Wilson Soc. Bull., 100:431-442. 
Potter, D. A. and D. W. Held. 2002. Biology and management of the Japanese beetle. Ann. Rev. Entom., 47:175-205.

Rock, P. 2005. Urban gulls: problems and solutions. Brit. Birds, 98:338-355.

Rosenberg, K. V. and R. J. Cooper. 1990. Approaches to avian diet analysis. Stud. Avian Biol., 13:80-90.

Sauer, J. R., J. E. Hines and J. Fallon. 2008. The North American Breeding Bird Survey, Results and Analysis 1966-2007. Version 5.15.2008. USGS Patuxent Wildlife Research Center, Laurel, Maryland. http://www.mbr-pwrc.usgs/bbs.html, accessed 08 Sep. 2008.

Triplehorn, C. A. And N. F. Johnson. 2005. Borror and Delong's Introduction to the study of insects. Seventh edition. Brook/Cole Publishing, Belmont, California. 864 p.

Vincent, J. F. V. And U. G. K. Wegst. 2004. Design and mechanical properties of insect cuticle. Arthro. Struc. Develop., 33:187-199.

Washburn, B. E., R. A. Dolbeer and G. E. Bernhardt. 2004. Laughing gull nest population in Jamaica Bay, New York, 1992-2004. Report to the Port Authority of New York and New Jersey, Jamaica, New York. 18 p.

R. B. Chipman And A. L. Gosser. 2005. Shooting gulls to reduce strikes with aircraft at John F. Kennedy International Airport, 1991-2004. Report to the Port Authority of New York and New Jersey, Jamaica, New York. 38 p.

Williams, R. E. AND W. B. Jackson. 1981. Dietary comparisons of red-winged blackbirds, brown-headed cowbirds, and European starlings in north-central Ohio. Ohio J. Sci., 81:217-225.

YDENBERG, R. C. 1994. The behavioral ecology of provisioning in birds. Ecoscience, 1:1-14.

ZAR, J. H. 1996. Biostatistical analysis. Third edition. Prentice-Hall Publishing, Upper Saddle River, New Jersey. $662 \mathrm{p}$. 